\title{
REVIEW
}

\section{Structure and functions of angiotensinogen}

\author{
Hong $\mathrm{Lu}^{1,2}$, Lisa A Cassis ${ }^{3}$, Craig W Vander Kooi ${ }^{4}$ and Alan Daugherty ${ }^{1,2,3}$ \\ Angiotensinogen (AGT) is the sole precursor of all angiotensin peptides. Although AGT is generally considered as a passive \\ substrate of the renin-angiotensin system, there is accumulating evidence that the regulation and functions of AGT are intricate. \\ Understanding the diversity of AGT properties has been enhanced by protein structural analysis and animal studies. In addition \\ to whole-body genetic deletion, AGT can be regulated in vivo by cell-specific procedures, adeno-associated viral approaches and \\ antisense oligonucleotides. Indeed, the availability of these multiple manipulations of AGT in vivo has provided new insights into \\ the multifaceted roles of AGT. In this review, the combination of structural and functional studies is highlighted to focus on the \\ increasing recognition that AGT exerts effects beyond being a sole provider of angiotensin peptides.
}

Hypertension Research (2016) 39, 492-500; doi:10.1038/hr.2016.17; published online 18 February 2016

Keywords: angiotensinogen; atherosclerosis; LoxP-Cre; obesity; structure

\section{INTRODUCTION}

The renin-angiotensin system (RAS) is pivotal to the regulation of blood pressure and homeostasis of water and sodium through actions of angiotensin II (AngII). Recently many other bioactive angiotensin peptides have been identified (Figure 1). The RAS is now recognized as a major regulator for a wide range of physiological and pathophysiological functions. Angiotensinogen (AGT) is the only precursor of all angiotensin peptides. Human AGT has 485 amino acids, including a 33 amino-acid signal peptide. The $10 \mathrm{~N}$-terminal amino acids are cleaved by renin to provide angiotensin I (AngI), which is the source for an array of active angiotensin peptides (Figure 1). The removal of AngI leaves a protein termed des(AngI)AGT. Despite des(AngI)AGT being $98 \%$ of the parent protein, its biological properties and fate are largely unknown. Indeed, even fundamental questions such as the relative concentrations of intact AGT vs. des(AngI)AGT in plasma and tissues have not been determined.

There is increasing acknowledgment that AGT is more than a mere passive substrate for the RAS. Recent studies have provided insights into new roles of AGT in both angiotensin peptide-dependent and -independent manners. We have discussed many biological properties of AGT in a recent review article. ${ }^{1}$ The present review will primarily focus on structural analysis and in vivo manipulations of AGT.

\section{STRUCTURE-FUNCTION OF ANGIOTENSINOGEN PROTEIN}

Structural model of AGT for AngI release

AGT is a member of the non-inhibitory serpin (serine protease inhibitor) superfamily. Other members of the serpin family include alphal antitrypsin, alphal antichymotrypsin and antithrombin III. The
N-terminus of AGT, encoding AngI, represents a unique extension compared with other serpin family members.

An initial model of AGT structure was developed by sequence alignment with ovalbumin, which is also an non-inhibitory serpin. ${ }^{2}$ The major tenets of this proposed structural model was confirmed when AGT was crystallized and the structure was resolved for recombinant non-glycosylated mouse, rat and human proteins. ${ }^{3}$ Non-glycosylated AGT has a molecular weight of $53 \mathrm{kDa}$ and can be present in states of up to $75 \mathrm{kDa}$ based on the extent of glycosylation. ${ }^{1}$ The variability of these glycosylation sites contributes to the difficulty in obtaining sufficient quality crystals to enable X-ray diffraction.

The cleavage of AGT by renin is the rate-limiting step to release AngI. The initial structural study implicates that renin cleavage efficacy can be facilitated by interactions with domains beyond the N-terminal amino acids of AGT. ${ }^{2}$ This speculation is partially based on the lower $\mathrm{Km}$ for AGT interactions with renin $(2.6 \mu \mathrm{M})$, compared with a chimera of alphal antitrypsin and the $17 \mathrm{~N}$-terminal amino acids of AGT interacting with renin $(47.5 \mu \mathrm{M}){ }^{2}{ }^{2}$ This $\mathrm{Km}$ is also lower than the isolated N-terminal tetradecapeptide of AGT. ${ }^{2}$ This initial analysis suggests that there are angiotensin-dependent roles of other regions beyond the N-terminus of AGT.

Renin cleavage of AGT also exhibits species specificity. For example, human AGT cannot be readily cleaved by mouse renin. This has been demonstrated in mice carrying human AGT transgene that requires co-expression of human renin to facilitate AngII production. ${ }^{4,5}$ It is assumed that the presence of Leu11-Tyr12 in mouse AGT vs. Val11-Ile12 in human AGT leads to impaired enzymatic kinetics of mouse renin to cleave human AGT. ${ }^{6}$ However, no studies

${ }^{1}$ Saha Cardiovascular Research Center, University of Kentucky, Lexington, KY, USA; ${ }^{2}$ Department of Physiology, University of Kentucky, Lexington, KY, USA; ${ }^{3}$ Department of Pharmacology and Nutritional Sciences, University of Kentucky, Lexington, KY, USA and ${ }^{4}$ Department of Molecular and Cellular Biochemistry, University of Kentucky, Lexington, KY, USA

Correspondence: Dr A Daugherty, Saha Cardiovascular Research Center, University of Kentucky, Biomedical Biological Sciences Research Building, B243, Lexington, KY 40536-0509, USA.

E-mail: Alan.Daugherty@uky.edu

Received 18 January 2016; revised 20 January 2016; accepted 21 January 2016; published online 18 February 2016 


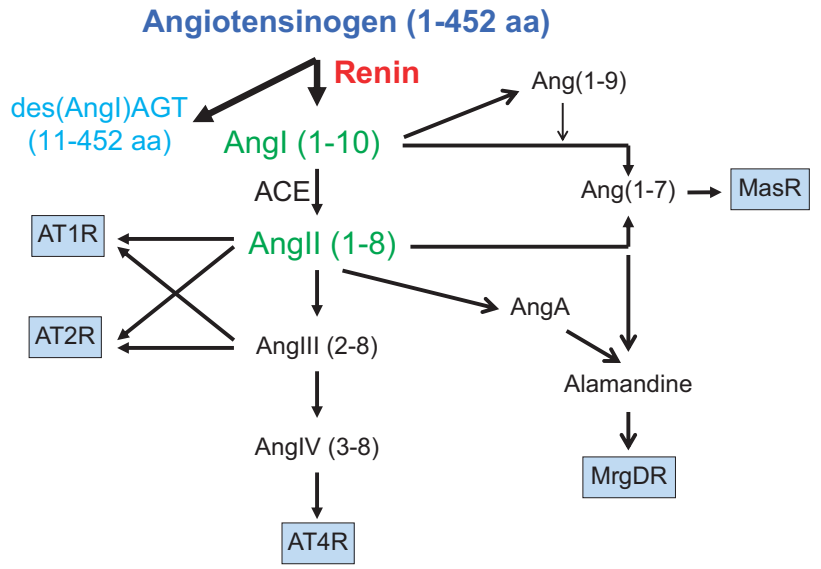

Figure 1 The renin-angiotensin cascade. Angiotensinogen is the substrate, and renin is its direct enzyme to generate all downstream angiotensin peptides. Numbers in parenthesis represent residue numbered starting from the N-terminus. 'aa' denotes 'amino acid'.

have directly determined whether replacing Leu11-Tyr12 in mouse AGT to Val11-Ile12 would impair mouse renin cleavage in vivo.

\section{Conserved Cys18-Cys138 disulfide bond in AngII-dependent functions}

The initial structural analysis has noted that cysteines at positions 18 and 138 of human AGT (Cys18-Cys137 in mice) have the potential to form an intermolecular disulfide bond that is conserved across species. ${ }^{2}$ A subsequent study has confirmed the presence of this disulfide bond. ${ }^{3}$ The AGT protein is secreted with the disulfide bond, which can be reduced by an unknown mechanism. Resolution of the crystal structure of AGT protein found that the renin cleavage site of AGT was buried in the AGT N-terminal tail. The conformational rearrangement that makes this site accessible for proteolysis has been revealed in human AGT and renin complex. ${ }^{3}$ The disulfide bridge was predicted to expose the N-terminus of AGT by a redoxdependent mechanism. Changes in $\mathrm{Km}$ during in vitro comparison of reduced $v s$. oxidized states were enhanced by inclusion of prorenin receptor protein in the reaction mixture. This structural analysis anticipates that the redox status of AGT represents a mechanism of AngII-dependent blood pressure regulation. Proof of principle for this prediction was provided by the greater ratio of oxidized vs. reduced AGT, determined using western blotting, in women afflicted with preeclampsia.

The role of the AGT disulfide bond in AngII release in vivo was determined in mice with substantial deficiency of endogenous AGT repopulated with native or mutated AGT using an adenoassociated viral (AAV) approach. ${ }^{7}$ Approximately $60 \%$ of plasma AGT is oxidized in humans, but plasma AGT is virtually completely oxidized in mice. Thus repopulation of AGT-depleted mice with a viral-derived native AGT should be optimized for renin cleavage, whereas repopulation of AGT in which the two cysteines are mutated to serines would render renin less efficiently on cleaving AGT. However, comparison of mice repopulated with native and mutated forms did not reveal differences in either AngII release or AngII-dependent effects, such as blood pressure and atherosclerosis. ${ }^{7}$ Findings from this animal study may not negate the potential role of this disulfide bond in AngI release in human; however, findings in women with preeclampsia ${ }^{3}$ needs to be validated by measuring both AngII and

\begin{tabular}{|l|l|}
\hline \multicolumn{1}{|c|}{ Species } & Sequence of Angll \\
\hline Human & DRVYIHPF \\
\hline Orangutan & DRVYIHPF \\
\hline Mouse & DRVYIHPF \\
\hline Rat & DRVYIHPF \\
\hline Cow & DRVYIHPF \\
\hline Horse & DRVYVHPF \\
\hline Guinea Pig & DRVYVHPF \\
\hline Chicken & DRVYVHPF \\
\hline Three-toed & DRVYVHPF \\
\hline Amphiumas & \\
\hline Alligator & DRVYIHPF \\
\hline Horn Fly & DRVYIHPF \\
\hline Zebra Fish & NRVYIHPF \\
\hline Silver Sea Bream & NRVYIHPF \\
\hline
\end{tabular}

Figure 2 Sequence conversation of Angll across species. Blue color represents conserved residues across species.

oxidized vs. reduced forms of AGT in a more precise quantitative method.

\section{Potentially functional conserved sequences in the core serpin} domain of AGT

Analysis of conservation in AGT provides significant insight into functionally important regions of the protein. For example, the eight amino acids encoding AngII are highly conserved across a wide range of species (Figure 2). In addition to the highly conserved AngII-encoding sequence, the core hydrophobic residues that stabilize the protein structure are also highly conserved. Additionally, comparison of sequence conservation of AGT protein has revealed interesting aspects on both the distal and proximal renin interacting surfaces of the protein. des(AngI)AGT encodes the core serpin domain, which contains other significant regions of conserved residues as mapped on the surface of the protein using Consurf, a web server for surface-mapping phylogenetic information (Figure 3). ${ }^{8}$ One conserved region is on the face proximal to AngI sequence, which is shown to directly contact renin. ${ }^{9}$ Although it is anticipated to contribute to the AngII-dependent functions of AGT, there is no direct experimental evidence for this hypothesis. On the face distal to the renin-binding surface, two highly conserved regions are also present. Because of the remote location, this face is unlikely to contribute to AngI release or AGT-renin interaction.

A few studies demonstrate that AGT exerts AngII-independent effects and des(AngI)AGT has direct biological properties. These include effects on renal function, blood-brain barrier, angiogenesis, adipose expansion and liver steatosis. ${ }^{9-15}$ The functional determination of these conserved regions and cross-species differences in vivo will provide insights into understanding the structural contribution of AGT to its catabolic fate and biological functions dependent and independent of AngI release. 


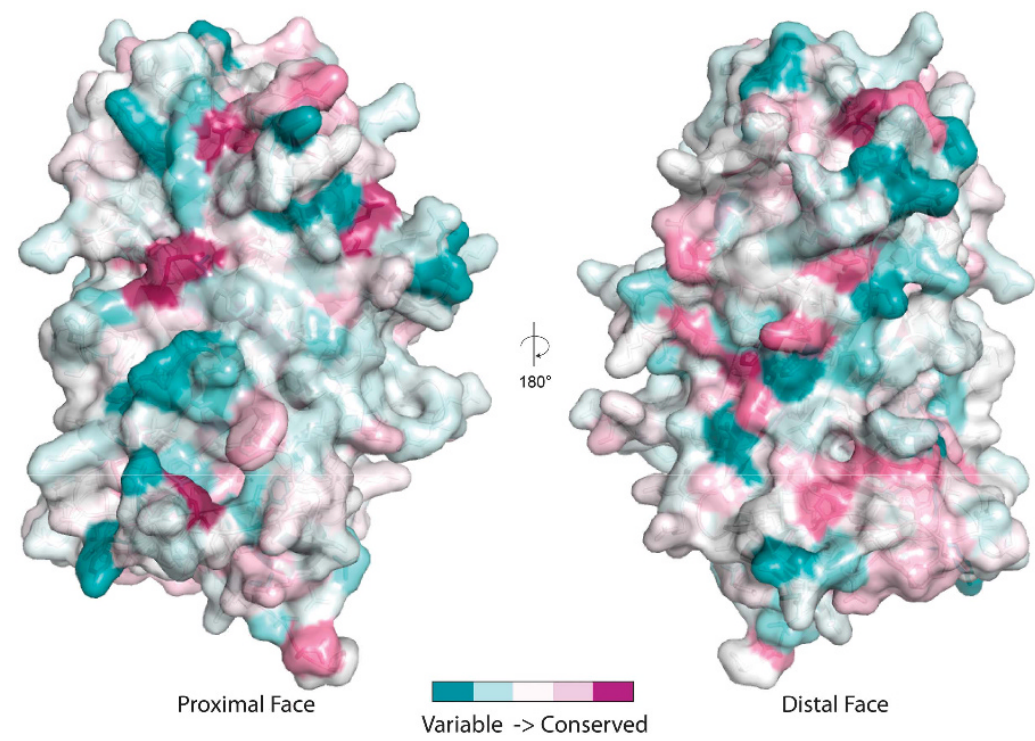

Figure 3 Conservation of surface residues in the core serpin domain of AGT. Sequences from human, rat, mouse, xenopus and zebrafish were aligned, and conservation was mapped on the surface of the protein (PDB 2XOB) using Consurf. Patches of pink residues indicate highly conserved regions, often important for physical interactions. In particular, the distal face, which has no assigned function, has significant regions of conservation.

\section{FUNCTIONAL CONSEQUENCES OF GENETIC OR PHARMACOLOGICAL MANIPULATIONS OF AGT}

Global deficiency or reduction of AGT through genetic manipulations

Mouse models with genetic manipulations of AGT are summarized in Table 1..$^{7,9,16-33}$ Whole-body AGT-deficient mice were developed in the 1990s by two research groups. ${ }^{16,17}$ These mice have low neonatal survival rate, impaired growth and renal development (Figure 4) and low blood pressure. Impaired growth is manifested by low birth body weight and stunted body weight gain during the development to adults, compared with their wild-type littermates. Whole-body deficiency of AGT leads to impaired body weight gain irrespective of normal or a fat-enriched diet feeding, less fat mass and higher locomotor activity in mice; ${ }^{18,19}$ an interesting contrast is that mice with human AGT and renin transgenes also have less body weight gain compared with their wild-type controls, although these mice have increased AGT and renin expression, resulting in increases of AngII productions. ${ }^{20}$ Therefore, the lean phenotype in these two mouse models cannot be explained by changes of AngII production.

As severe health issues in whole-body AGT-deficient mice hamper its use, AGT floxed mice were developed to determine its biological and pathophysiological functions. ${ }^{7,9}$ In an initially developed AGT floxed mice, the neo cassette in the targeting gene was not removed. Inclusion of the neo cassette resulted in whole-body reductions of AGT but did not compromise neonatal survival rate, general growth and kidney development. ${ }^{9}$ Therefore, this is an AGT hypomorphic (hypoAGT) mouse model. HypoAGT mice in an low-density lipoprotein (LDL) receptor $-/$ - background have lower blood pressure and nearly ablated atherosclerotic lesions, compared with their wild-type littermates. These two effects are expected because high blood pressure and atherosclerosis are two well-recognized AngIIdependent effects in hypercholesterolemic mice. ${ }^{34-39}$ Unexpectedly, although hypoAGT mice have comparable body weight as their wild-type littermates when fed a normal laboratory diet, these mice have diminished body weight gain and liver steatosis when they are fed a diet that has a fat content $(42 \% \mathrm{kcal}$ from saturated fat) similar to the average dietary composition of Western nations. ${ }^{9}$

\section{Cell-specific depletion of AGT using Cre-LoxP technique}

Cre-LoxP technique has been used extensively in the past decade to determine cell-specific effects of genes. In earlier studies to understand AGT biological properties, this technique was applied to mice with human AGT transgene or both human AGT and renin transgenes. 33,40 In mice expressing human AGT transgene, depletion of human AGT specifically in the brain leads to ablated blood pressure responses to human renin infusion into brain. ${ }^{40}$ In mice with both human AGT and renin transgene expression specifically in the brain, brain AngII is increased, but peripheral AngII is reduced. ${ }^{33}$ These mice have lower body weight (Table 1), higher sympathetic nervous activity and increased energy expenditure. Increased metabolic rates in these mice are attenuated by blockade of beta-adrenergic activity or increases of peripheral AngII level. It is worth noting that these mice are not healthy with one-third of mice dying prior to weaning, possibly owing to deficiency in retaining sodium. Findings from these studies infer that AngII production in the brain regulates functions in peripheral organs.

Recently, four research groups have reported AGT floxed mice with cell-specific deletion (Table 1). ${ }^{7,9,26-29}$ AGT is expressed in adipocytes, ${ }^{41,42}$ and findings from in vitro studies have implicated that AGT derived from this cell type promotes obesity and cardiovascular disease. ${ }^{43}$ To directly determine the role of adipocyte-derived AGT, AGT floxed mice were bred to those expressing Cre under the control of the AP2 promoter. An initial study found that adipocytespecific deletion of AGT reduced its plasma concentrations by 24-28\%, accompanied by reductions of blood pressure. These changes occurred in the absence of effects on body weight, fat mass, adipocyte size or glucose homeostasis. ${ }^{27} \mathrm{~A}$ subsequent study determined effects of adipocyte-specific AGT deletion on blood pressure in mice fed a diet containing either low fat $(10 \% \mathrm{kcal})$ or high fat $(60 \% \mathrm{kcal})$. Plasma AGT concentrations were unchanged in these mice, but systolic blood pressure was decreased, compared with their wild-type controls. ${ }^{28}$ As with mice fed a normal laboratory diet, body weight was not influenced in mice fed the $60 \%$ fat diet but modestly increased in mice fed the $10 \% \mathrm{kcal}$ fat diet. ${ }^{28}$ Another study in adipocyte-specific AGT-deleted mice failed to demonstrate effects on body weight when 

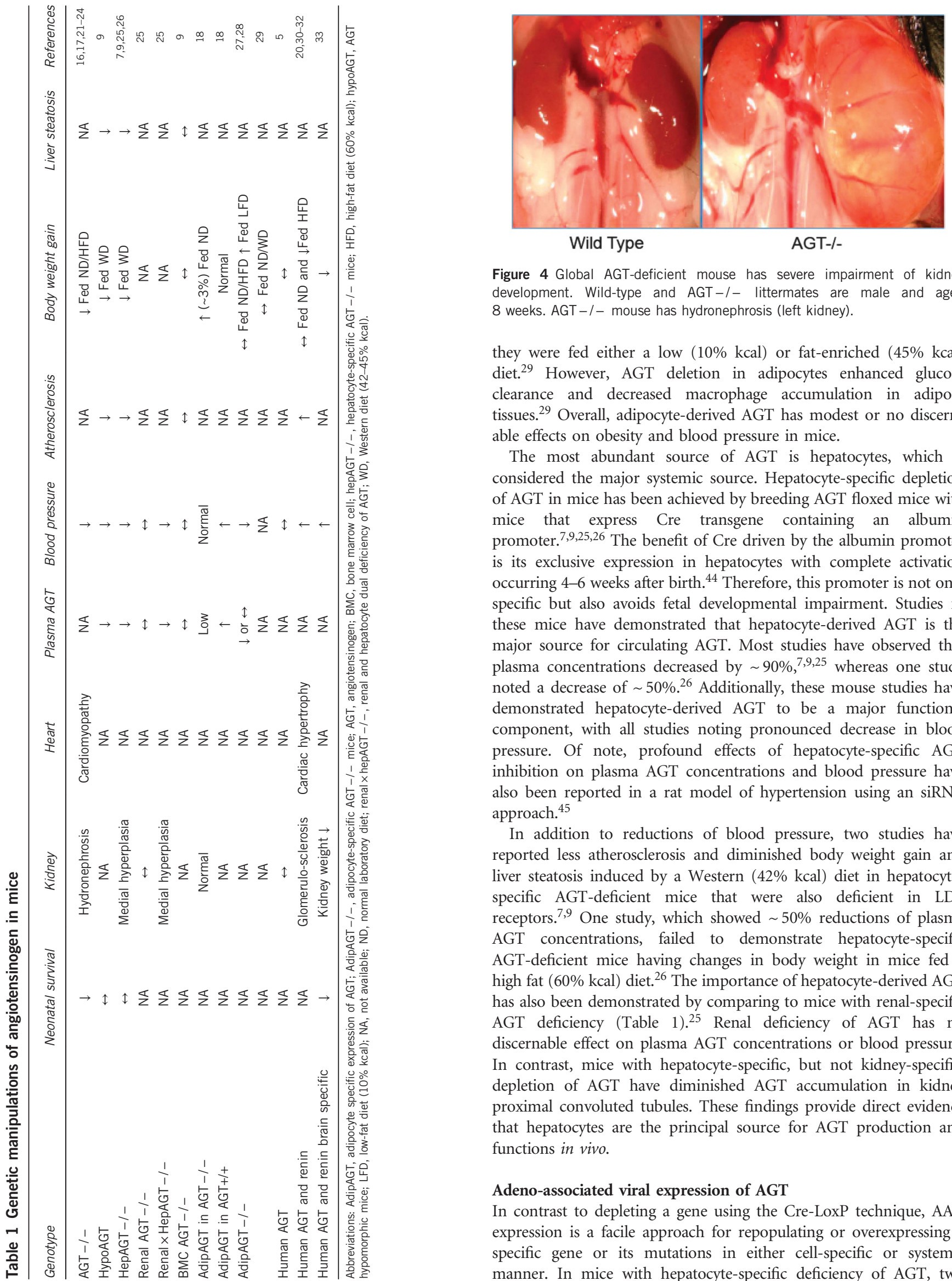

Figure 4 Global AGT-deficient mouse has severe impairment of kidney development. Wild-type and AGT-/- littermates are male and aged 8 weeks. AGT-/- mouse has hydronephrosis (left kidney).

they were fed either a low (10\% kcal) or fat-enriched $(45 \% \mathrm{kcal})$ diet. ${ }^{29}$ However, AGT deletion in adipocytes enhanced glucose clearance and decreased macrophage accumulation in adipose tissues. ${ }^{29}$ Overall, adipocyte-derived AGT has modest or no discernable effects on obesity and blood pressure in mice.

The most abundant source of AGT is hepatocytes, which is considered the major systemic source. Hepatocyte-specific depletion of AGT in mice has been achieved by breeding AGT floxed mice with mice that express Cre transgene containing an albumin promoter. ${ }^{7,9,25,26}$ The benefit of Cre driven by the albumin promoter is its exclusive expression in hepatocytes with complete activation occurring 4-6 weeks after birth. ${ }^{44}$ Therefore, this promoter is not only specific but also avoids fetal developmental impairment. Studies in these mice have demonstrated that hepatocyte-derived AGT is the major source for circulating AGT. Most studies have observed that plasma concentrations decreased by $\sim 90 \%,{ }^{7,9,25}$ whereas one study noted a decrease of $\sim 50 \%{ }^{26}$ Additionally, these mouse studies have demonstrated hepatocyte-derived AGT to be a major functional component, with all studies noting pronounced decrease in blood pressure. Of note, profound effects of hepatocyte-specific AGT inhibition on plasma AGT concentrations and blood pressure have also been reported in a rat model of hypertension using an siRNA approach. ${ }^{45}$

In addition to reductions of blood pressure, two studies have reported less atherosclerosis and diminished body weight gain and liver steatosis induced by a Western $(42 \% \mathrm{kcal})$ diet in hepatocytespecific AGT-deficient mice that were also deficient in LDL receptors. ${ }^{7,9}$ One study, which showed $\sim 50 \%$ reductions of plasma AGT concentrations, failed to demonstrate hepatocyte-specific AGT-deficient mice having changes in body weight in mice fed a high fat $(60 \% \mathrm{kcal})$ diet. $^{26}$ The importance of hepatocyte-derived AGT has also been demonstrated by comparing to mice with renal-specific AGT deficiency (Table 1). ${ }^{25}$ Renal deficiency of AGT has no discernable effect on plasma AGT concentrations or blood pressure. In contrast, mice with hepatocyte-specific, but not kidney-specific, depletion of AGT have diminished AGT accumulation in kidney proximal convoluted tubules. These findings provide direct evidence that hepatocytes are the principal source for AGT production and functions in vivo.

Adeno-associated viral expression of AGT

In contrast to depleting a gene using the Cre-LoxP technique, AAV expression is a facile approach for repopulating or overexpressing a specific gene or its mutations in either cell-specific or systemic manner. In mice with hepatocyte-specific deficiency of AGT, two 
studies have reported repopulation of manipulated AGT gene through a single i.p. injection of AAVs that contain a hepatocyte-specific promoter thyroxine-binding globulin. ${ }^{7,9}$ In a study described earlier, mutation of the Cys18-Cys137 disulfide bond did not affect renin cleavage of AGT to release AngI and did not regulate production and functions of AngII in hepatocyte-specific AGT-deficient mice. ${ }^{7}$ In a subsequent study, AAVs containing either mouse full-length AGT or des(AngI)AGT were injected into mice with hepatocyte-specific deficiency of AGT. This approach in mice lacking circulating AGT resulted in restoration of either full-length AGT that could be cleaved into AngI and des(AngI)AGT or des(AngI)AGT alone without increasing AngI. Repopulation of full-length AGT increased AngII production, blood pressure, atherosclerosis, diet-induced body weight gain and liver steatosis, whereas repopulation of des(AngI)AGT did not affect AngII production and atherosclerosis but increased dietinduced body weight gain and liver steatosis. ${ }^{79}$ These studies provide direct evidence that AGT contributes to diet-induced obesity and liver steatosis through des(AngI)AGT-mediated mechanisms, which are independent of AngII.

\section{Antisense Oligonucleotides (ASO) against AGT}

ASO against AGT targets AGT mRNA, leading to its degradation, thereby reducing AGT protein production. Three recent studies have reported that mouse AGT ASO inhibits AGT mRNA in major organs such as the liver, kidney and adipose tissues. ${ }^{9,46,47}$ Inhibition of mouse AGT mRNA synthesis attenuates kidney dysfunction in mouse models with polycystic kidney disease ${ }^{46,47}$ and reduces blood pressure, atherosclerosis and obesity in hypercholesterolemic mice. ${ }^{9}$ These findings are consistent with phenotypes observed in mice with AGT deletions using genetic approaches. ${ }^{9}$ Compared with mice manipulated genetically, there are several benefits of using AGT ASO. First, this pharmacological approach can be used in adult mice, thereby avoiding potential impairments on development and normal growth. Second, this approach can be used to study established pathological conditions. For example, in LDL receptor $-/$ - mice fed a Western diet for 12 weeks, atherosclerosis and obesity were established prior to pharmacological intervention. Administration of AGT ASO into mice with these established diseases attenuated further progression of atherosclerosis and regressed preexisting obesity. ${ }^{9}$ Most importantly and of clinical relevance, ASO is a potential approach for treating human diseases. Two pharmaceutical companies, Alnylam and Ionis, have announced development of ASO for reducing AGT synthesis in humans for preeclampsia and resistant hypertension, respectively.

\section{COMPARISONS OF GENETIC AND PHARMACOLOGICAL INHIBITIONS BETWEEN AGT AND OTHER CLASSIC RENIN- ANGIOTENSIN COMPONENTS}

Many components of the RAS have been studied in whole-body deficient mice of several components of the system. Consistent with phenotypes observed in mice with whole-body deficiency of AGT, global deficiency of renin ${ }^{48}$ or angiotensin-converting enzyme (ACE) $)^{49}$ or co-deficiency of AT1a and AT1b receptors ${ }^{50}$ also leads to low neonatal survival rate, impaired growth and renal development and low blood pressure. Global deficiency of all these components also have 'beneficial' effects on obesity as reported in the literature. ${ }^{51,52}$ However, their severe growth and health impairments compromise this phenotype interpretation. Table 2 summarizes the phenotypes reported in mice with genetic depletions of renin, ACE or AngII receptors. ${ }^{22,34,36,48-66}$ As outlined in both Tables 1 and 2, it is clear that mice with whole-body deficiency of a key member in the RAS have severe phenotypes such as impairments of kidney and heart development, general growth and low blood pressure that are attributed to either depleted AngII production (whole-body deficiency of AGT, renin or ACE) or interrupted AngII-AT1 receptor interaction (AT1a and AT1b co-deficiency), thereby being AngII-dependent phenotypes.

Genetic mouse models of AGT, renin or ACE deficiency have lower body weight that may be attributed to developmental impairment. In contrast, pharmacological inhibition of the renin angiotensin components in adult mice does not affect development and body growth. In an unbiased literature search using the key words 'renin inhibition', 'aliskiren', 'angiotensin-converting enzyme', 'ACE inhibitor', 'AT1 receptor blockers', AT1 receptor antagonists', combined with 'body weight' and 'mouse', 85 studies determined effects of pharmacological renin-angiotensin inhibition on body weight in mice. The majority of studies report that renin-angiotensin inhibition does not change body weight in adult mice. A small number of manuscripts (total 17 of 85; renin inhibition: 2 of 11; ACE inhibition: 4 of 25 and AT1 receptor blockade: 11 of 49) report renin-angiotensin inhibition attenuating

Table 2 Genetic manipulations of renin, ACE or Angll receptors in mice

\begin{tabular}{|c|c|c|c|c|c|c|c|c|}
\hline Genotype & Neonatal survival & Kidney & Heart & Blood pressure & Atherosclerosis & Body weight & Liver steatosis & References \\
\hline Renin -/ - & $\downarrow$ & Hydronephrosis & NA & $\downarrow$ & NA & $\begin{array}{l}\downarrow \text { Fed ND/HFD } \\
\downarrow \text { Fat absorption }\end{array}$ & $\downarrow$ & 48,51 \\
\hline $\mathrm{BMC}$ renin -/- & NA & NA & NA & $\leftrightarrow$ & $\downarrow$ & $\leftrightarrow$ & NA & 36 \\
\hline Human renin & NA & NA & NA & $\leftrightarrow$ & NA & $\begin{array}{c}\uparrow \text { Fed ND } \\
(\uparrow \text { food intake) }\end{array}$ & $\uparrow$ at 60 weeks & $53-55$ \\
\hline $\mathrm{ACE}-1-$ & $\downarrow$ & Hydronephrosis & NA & $\downarrow$ & NA & $\downarrow$ Fed ND/HFD & NA & $22,49,52$ \\
\hline BMC ACE - /- & NA & NA & NA & $\leftrightarrow$ & $\downarrow$ & $\leftrightarrow$ & NA & 56 \\
\hline AT1aR -/- & $\downarrow$ or $\leftrightarrow$ & $\leftrightarrow$ & $\leftrightarrow$ & $\downarrow$ or $\leftrightarrow$ & $\downarrow$ & $\leftrightarrow$ & $\downarrow$ & $34,57-61$ \\
\hline AT1bR - / - & $\leftrightarrow$ & $\leftrightarrow$ & $\leftrightarrow$ & $\leftrightarrow$ & $\leftrightarrow$ & $\leftrightarrow$ & NA & $50,62,63$ \\
\hline AT1aR $-/-\times$ AT1bR -/- & $\downarrow$ & Hydronephrosis & Cardiomyopathy & $\downarrow$ & NA & $\downarrow$ Fed ND & NA & $50,62,64$ \\
\hline AT2R $-/-$ & $\leftrightarrow$ & $\leftrightarrow$ & $\leftrightarrow$ & $\leftrightarrow$ & $\leftrightarrow$ & $\leftrightarrow$ Fed ND/HFD & $\leftrightarrow$ & $34,62,65,66$ \\
\hline AT1aR - / - $\times$ AT2R - / - & $\leftrightarrow$ & Glomerular atrophy & Cardiac atrophy & $\downarrow(\mathrm{MAP})$ & NA & $\leftrightarrow$ Fed ND & NA & 62,64 \\
\hline AT1bR $-/-\times$ AT2R $-/-$ & $\leftrightarrow$ & $\leftrightarrow$ & $\leftrightarrow$ & $\leftrightarrow(\mathrm{MAP})$ & NA & $\uparrow$ & NA & 62,64 \\
\hline $\begin{array}{l}\text { AT1aR }-/-\times \text { AT1bR }-/-\times \\
\text { AT2R }-/-\end{array}$ & $\downarrow$ & Hydronephrosis & Cardiac atrophy & $\downarrow(\mathrm{MAP})$ & NA & $\downarrow$ Fed ND & NA & 62,64 \\
\hline
\end{tabular}

Abbreviations: ACE, angiotensin-converting enzyme; BMC, bone marrow cell; HFD, high-fat diet; MAP, mean arterial pressure; NA, not available; ND, normal diet. 
body weight gain. However, body weight changes in most studies are either modest during certain intervals or attributed to reduced food intake. Table 3 summarizes effects of renin inhibition on body weight in mice. ${ }^{9,36,38,67-74}$ Among 11 articles that have studied effects of renin inhibition on body weight, 2 articles report that aliskiren reduces body weight gain. In one study, ${ }^{67}$ aliskiren $\left(50 \mathrm{mg} \mathrm{kg} \mathrm{day}^{-1}\right.$ for 6 weeks) leads to reduced body weight gain of $<5 \%$ in a few intervals during 6 weeks of normal or a high-fat diet feeding in C57BL/6 mice. The other study reports that aliskiren ( $50 \mathrm{mg} \mathrm{kg} \mathrm{day}^{-1}$ for 14 days) reduces body weight gain by approximately $10 \%$ in a type 2 diabetic mouse model, KK-Ay. ${ }^{68}$ In addition to the modest changes of body weight in these two studies, it is worth noting that high dose of aliskiren induces skin necrosis, resulting in impairment of health. Therefore, it is important to record whether reductions of body weight in mice administered aliskiren is related to skin necrosis or other health concerns. Overall, although genetic deletion of renin, ACE or AngII receptors leads to dramatic phenotypes on body weight, these have not been consistently mimicked by pharmacological inhibition of these same RAS components in adult animals. This dichotomy is possibly due to phenotypes in whole-body deficient mice being attributed to developmental defects rather than reductions in RAS activity.

In contrast to extensive studies on other components of the RAS, effects of AGT inhibition have not been explored owing to the lack of pharmacological agents that directly target this protein. The lack of efforts in developing an AGT inhibitor may be attributable to the common thought that it would provide no additional benefits over the three existing modes of RAS inhibitors. In contrast to this thought, a recent study has demonstrated that inhibition of AGT using ASO not only reduces blood pressure and atherosclerosis but also diminishes body weight gain. ${ }^{9}$ Both inhibition of AGT and renin diminishes generation of downstream angiotensin peptides. ASO against AGT reduces intact AGT and des(AngI)AGT, leading to reductions of total AGT, whereas renin inhibition increases intact AGT and reduces des (AngI)AGT with no changes of total plasma AGT. In agreement with AGT inhibition, renin inhibition reduces blood pressure and atherosclerosis; however, it has no effect on diet-induced obesity. These findings support the concept that AGT has both AngII-dependent and -independent functions.

Collectively, in contrast to inconsistencies of body weight and its related phenotypes between whole-body genetic manipulations and pharmacological inhibitions of renin, ACE or AT1 receptors, AGT functions are consistently defined by cell-specific genetic manipulations, AAV administration and pharmacological inhibition using ASOs.

\section{ASSOCIATIONS OF AGT POLYMORPHISMS WITH PATHOPHYSIOLOGICAL FUNCTIONS IN HUMANS}

Mapping single-nucleotide polymorphisms is extensively used in genome-wide association studies to identify functional variations in DNA sequences. Two missense mutations, T174M and M235T, and multiple single-nucleotide polymorphisms, including $\mathrm{A}(-6) \mathrm{G}$ and $\mathrm{A}$ $(-20) \mathrm{C}$ in the promoter region of the human AGT gene, have been comprehensively studied. ${ }^{75}$ These polymorphisms, for example, M235 and $\mathrm{A}(-6)$, are in close linkage disequilibrium. M235T is associated with plasma AGT concentrations. ${ }^{76}$ Although this polymorphism has been reported to be associated with essential hypertension in many studies (as few examples, please refer $^{76-80}$ ), others do not observe this association. ${ }^{81-87}$ Similar to M235T, other polymorphisms identified in the human AGT gene are also not consistently associated with pathophysiological conditions in humans. These polymorphisms are not in the range of conserved sequences in the core serpin domain as predicted on the AGT protein structure shown in Figure 3. It is unclear whether the inconsistent findings are due to that these polymorphisms do not have linkage with functional, conserved residues of the AGT protein.

Irrespective of genetic polymorphisms, plasma AGT concentrations are increased in obese people ${ }^{88}$ but decreased with weight loss. ${ }^{89,90}$ However, changes of AGT expression in adipocytes of obese and non-obese populations have not been consistent. ${ }^{88-92}$ There is a report that AGT mRNA levels in mature adipocytes are inversely correlated with the size of adipocytes, ${ }^{88}$ and there is also a report that mRNA of AGT in human adipose tissue is significantly reduced in obese subjects compared with normal subjects. ${ }^{90}$ One study reports that body weight correlates independently and positively with mRNA expression of AGT in patients undergoing either gastric banding or elective laparoscopic cholecystectomy, ${ }^{93}$ whereas another study from the same investigators reports that mRNA expression of AGT is not associated with body mass index in 20 patients undergoing weight reduction surgery with adjustable gastric banding. ${ }^{91}$ Similar conflicting findings have also been reported in animal studies. ${ }^{94,95}$ These conflicting

Table 3 Effects of renin inhibition by aliskiren on multiple pathological conditions in mice

\begin{tabular}{|c|c|c|c|c|c|c|c|c|}
\hline Mouse strain & Aliskiren mg kg day ${ }^{-1}$ (duration) & Diet & Food intake & Blood pressure & Atherosclerosis & Body weight gain & Liver steatosis & References \\
\hline KK-Ay (F) & 50 (2 weeks) & Normal & NA & $\downarrow$ & NA & $\downarrow \sim 10 \%$ & NA & 68 \\
\hline \multirow[t]{5}{*}{ C57BL/6 (M) } & 50 (6 weeks) & $10 \% \mathrm{kcal}$ from fat & $\leftrightarrow$ & NA & NA & $\downarrow \sim 4 \%$ & NA & 67 \\
\hline & & $45 \% \mathrm{kcal}$ from fat & $\leftrightarrow$ & NA & NA & $\downarrow \sim 4 \%$ & NA & \\
\hline & 3,10 (2 weeks) & NA & NA & $\leftrightarrow$ & NA & $\leftrightarrow$ & NA & 69 \\
\hline & 25,50 (2 weeks) & NA & NA & $\downarrow$ & NA & $\leftrightarrow$ & NA & \\
\hline & $50(6 \text { weeks })^{a}$ & $50 \%$ kcal from fat & $\leftrightarrow$ & $\downarrow$ & NA & $\leftrightarrow$ & NA & 70 \\
\hline C57BL/6 (M) and STZ & 20 & NA & NA & $\leftrightarrow$ & NA & $\leftrightarrow$ & NA & 71 \\
\hline \multirow[t]{3}{*}{$L d l r^{-/-}(\mathrm{M})$} & $2.5,25$ or 50 (12 weeks) & $42 \% \mathrm{kcal}$ from fat & NA & $\downarrow$ & $\downarrow$ & $\leftrightarrow$ & NA & 36 \\
\hline & $2.5,12.5$ or 25 (12 weeks) & $42 \% \mathrm{kcal}$ from fat & NA & $\downarrow$ & $\downarrow$ & $\leftrightarrow$ & NA & 38 \\
\hline & 12.5 (12 weeks) & $42 \% \mathrm{kcal}$ from fat & NA & $\downarrow$ & $\downarrow$ & $\leftrightarrow$ & $\leftrightarrow$ & 9 \\
\hline \multirow[t]{4}{*}{$\mathrm{db} / \mathrm{db}(\mathrm{M})$} & 3 (6 weeks) & Normal & NA & $\leftrightarrow$ & NA & $\leftrightarrow$ & NA & 72 \\
\hline & $6,12,25$ (6 weeks) & Normal & NA & $\downarrow$ & NA & $\leftrightarrow$ & NA & \\
\hline & 25 (12 weeks) & NA & NA & NA & NA & $\leftrightarrow$ & $\leftrightarrow$ & 73 \\
\hline & 25,50 (15 days) & $42 \% \mathrm{kcal}$ from fat & NA & NA & NA & $\leftrightarrow$ & NA & 74 \\
\hline
\end{tabular}


findings, combined with findings that adipocyte-specific deficiency of AGT has no effects on body weight gain as demonstrated in mice, ${ }^{23,28,29}$ implicate that adipose-derived AGT is not a major contributor to AGT-mediated body weight changes.

\section{CONCLUSIONS AND PERSPECTIVES}

There is accumulating evidence that AGT has functions in addition to serving as the essential source of angiotensin peptides. The significance of exploring AGT structure and biological functions will be enhanced by evolving pharmacological strategies, as the protein is now a therapeutic target of two companies (Alnylam and Ionis), who have announced development of ASOs for reducing AGT synthesis in humans. Despite AGT being the only source of the entire angiotensin peptide system, many fundamental questions of AGT biological properties still need to be answered: (1) Which conserved residues of AGT contribute to AngII-dependent and -independent effects? (2) What are the molecular mechanisms by which AGT regulates obesity and liver steatosis? Are these direct effects or indirect effects through a specific pathway or multiple signaling pathways? (3) How and why does AGT produced in hepatocytes contribute to functions in other tissues and organs such as the kidney and adipose tissues? and (4) Do AGT and des(AngI)AGT have their own receptors?

\section{CONFLICT OF INTEREST}

The authors declare no conflict of interest.

\section{ACKNOWLEDGEMENTS}

Our research work is supported by a grant from the National Institutes of Health (HL107319 to Alan Daugherty) and a pilot grant to Hong Lu by an Institutional Development Award from the National Institute of General Medical Sciences of the National Institutes of Health under grant number P20 GM103527.

1 Wu C, Lu H, Cassis LA, Daugherty A. Molecular and pathophysiological features of angiotensinogen: a mini review. N Am J Med Sci (Boston) 2011; 4: 183-190.

2 Streatfeild-James RM, Williamson D, Pike RN, Tewksbury D, Carrell RW, Coughlin PB. Angiotensinogen cleavage by renin: importance of a structurally constrained $\mathrm{N}$-terminus. FEBS Lett 1998; 436: 267-270.

3 Zhou A, Carrell RW, Murphy MP, Wei Z, Yan Y, Stanley PL, Stein PE, Broughton Pipkin $F$, Read RJ. A redox switch in angiotensinogen modulates angiotensin release. Nature 2010; 468: 108-111.

4 Fukamizu A, Sugimura K, Takimoto E, Sugiyama F, Seo MS, Takahashi S, Hatae T, Kajiwara N, Yagami K, Murakami K. Chimeric renin-angiotensin system demonstrates sustained increase in blood pressure of transgenic mice carrying both human renin and human angiotensinogen genes. J Biol Chem 1993; 268: 11617-11621.

5 Yang G, Merrill DC, Thompson MW, Robillard JE, Sigmund CD. Functional expression of the human angiotensinogen gene in transgenic mice. J Biol Chem 1994; 269: 32497-32502.

6 Hatae T, Takimoto E, Murakami K, Fukamizu A. Comparative studies on speciesspecific reactivity between renin and angiotensinogen. Mol Cell Biochem 1994; 131: 43-47.

7 Wu C, Xu Y, Lu H, Howatt DA, Balakrishnan A, Moorleghen JJ, Kooi CW, Cassis LA, Wang JA, Daugherty A. Cys18-Cys137 disulfide bond in mouse angiotensinogen does not affect Angll-dependent functions in vivo. Hypertension 2015; 65: 800-805.

8 Glaser F, Pupko T, Paz I, Bell RE, Bechor-Shental D, Martz E, Ben-Tal N. ConSurf: identification of functional regions in proteins by surface-mapping of phylogenetic information. Bioinformatics 2003; 19: 163-164.

9 Lu H, Wu C, Howatt DA, Balakrishnan A, Moorleghen JJ, Chen X, Zhao M, Graham MJ, Mullick AE, Crooke RM, Feldman DL, Cassis LA, Vander Kooi CW, Daugherty A. Angiotensinogen exerts effects independent of angiotensin II. Arterioscler Thromb Vasc Biol 2016; 36: 256-265.

10 Kakinuma Y, Hama H, Sugiyama F, Yagami K, Goto K, Murakami K, Fukamizu A. Impaired blood-brain barrier function in angiotensinogen-deficient mice. Nat Med 1998; 4: 1078-1080.

11 Celerier J, Cruz A, Lamande N, Gasc JM, Corvol P. Angiotensinogen and its cleaved derivatives inhibit angiogenesis. Hypertension 2002; 39: 224-228.

12 Bouquet C, Lamande N, Brand M, Gasc JM, Jullienne B, Faure G, Griscelli F, Opolon P, Connault $E$, Perricaudet M, Corvol P. Suppression of angiogenesis, tumor growth, and metastasis by adenovirus-mediated gene transfer of human angiotensinogen. Mol Ther 2006; 14: 175-182.

13 Corvol P, Lamande N, Cruz A, Celerier J, Gasc JM. Inhibition of angiogenesis: a new function for angiotensinogen and des(angiotensin I)angiotensinogen. Curr Hypertens Rep 2003; 5: 149-154.

14 Vincent F, Bonnin P, Clemessy M, Contreres JO, Lamande N, Gasc JM, Vilar J, Hainaud P, Tobelem G, Corvol P, Dupuy E. Angiotensinogen delays angiogenesis and tumor growth of hepatocarcinoma in transgenic mice. Cancer Res 2009; 69: 2853-2860.

15 Brand M, Lamande N, Larger E, Corvol P, Gasc JM. Angiotensinogen impairs angiogenesis in the chick chorioallantoic membrane. J Mol Med (Berl) 2007; 85: 451-460.

16 Tanimoto K, Sugiyama F, Goto Y, Ishida H, Takimoto E, Yagami K, Fukamizu A, Murakami K. Angiotensinogen-deficient mice with hypotension. J Biol Chem 1994; 269: 31334-31337.

17 Kim HS, Krege JH, Kluckman KD, Hagaman JR, Hodgin JB, Best CF, Jennette JC, Coffman TM, Maeda N, Smithies O. Genetic control of blood pressure and the angiotensinogen locus. Proc Natl Acad Sci USA 1995; 92: 2735-2729.

18 Massiera F, Bloch-Faure M, Ceiler D, Murakami K, Fukamizu A, Gasc JM, QuignardBoulange A, Negrel R, Ailhaud GSJ, Meneton P, Teboul M. Adipose angiotensinogen is involved in adipose tissue growth and blood pressure regulation. FASEB J 2001; 15: 2727-2729.

19 Kim S, Urs S, Massiera F, Wortmann P, Joshi R, Heo YR, Andersen B, Kobayashi H, Teboul M, Ailhaud G, Quignard-Boulange A, Fukamizu A, Jones BH, Kim JH, MoustaidMoussa N. Effects of high-fat diet, angiotensinogen (agt) gene inactivation, and targeted expression to adipose tissue on lipid metabolism and renal gene expression. Horm Metab Res 2002; 34: 721-725.

20 Favre GA, Lebrun P, Lopez P, Butori C, Hofman P, Esnault VL, Van Obberghen E. Constitutive activation of the renin-angiotensin system reduces visceral fat and improves glucose tolerance in mice. J Renin Angiotensin Aldosterone Syst 2014; 15: 396-409.

21 Nagata M, Tanimoto K, Fukamizu A, Kon Y, Sugiyama F, Yagami K, Murakami K, Watanabe T. Nephrogenesis and renovascular development in angiotensinogendeficient mice. Lab Invest 1996; 75: 745-753.

22 Davisson RL, Kim HS, Krege JH, Lager DJ, Smithies O, Sigmund CD. Complementation of reduced survival, hypotension, and renal abnormalities in angiotensinogen-deficient mice by the human renin and human angiotensinogen genes. J Clin Invest 1997; 99: 1258-1264.

23 Massiera F, Seydoux J, Geloen A, Quignard-Boulange A, Turban S, Saint-Marc P, Fukamizu A, Negrel R, Ailhaud G, Teboul M. Angiotensinogen-deficient mice exhibit impairment of diet-induced weight gain with alteration in adipose tissue development and increased locomotor activity. Endocrinology 2001; 142: 5220-5225.

24 Sumida Y, Umemura S, Tamura K, Kihara M, Kobayashi S, Ishigami T, Yabana M, Nyui $\mathrm{N}$, Ochiai H, Fukamizu A, Miyazaki H, Murakami K, Ishii M. Increased cardiac angiotensin II receptors in angiotensinogen-deficient mice. Hypertension 1998; 31: 45-49.

25 Matsusaka T, Niimura F, Shimizu A, Pastan I, Saito A, Kobori H, Nishiyama A, Ichikawa I. Liver angiotensinogen is the primary source of renal angiotensin II. J Am Soc Nephrol 2012; 23: 1181-1189.

26 Yiannikouris F, Wang Y, Shoemaker R, Larian N, Thompson J, English VL, Charnigo R, Su W, Gong M, Cassis LA. Deficiency of angiotensinogen in hepatocytes markedly decreases blood pressure in lean and obese male mice. Hypertension 2015; 66: $836-842$.

27 Yiannikouris F, Karounos M, Charnigo R, English VL, Rateri DL, Daugherty A, Cassis LA. Adipocyte-specific deficiency of angiotensinogen decreases plasma angiotensinogen concentration and systolic blood pressure in mice. Am J Physiol Regul Integr Comp Physiol 2012; 302: R244-R251.

28 Yiannikouris F, Gupte M, Putnam K, Thatcher S, Charnigo R, Rateri DL, Daugherty A, Cassis LA. Adipocyte deficiency of angiotensinogen prevents obesity-induced hypertension in male mice. Hypertension 2012; 60: 1524-1530.

29 LeMieux MJ, Ramalingam L, Mynatt RL, Kalupahana NS, Kim JH, Moustaid-Moussa N. Inactivation of adipose angiotensinogen reduces adipose tissue macrophages and increases metabolic activity. Obesity (Silver Spring) 2016; 24: 359-367.

30 Merrill DC, Thompson MW, Carney CL, Granwehr BP, Schlager G, Robillard JE, Sigmund $\mathrm{CD}$. Chronic hypertension and altered baroreflex responses in transgenic mice containing the human renin and human angiotensinogen genes. J Clin Invest 1996; 97: 1047-1055.

31 Kai T, Kino H, Sugimura K, Shimada S, Kurooka A, Akamatsu K, Takenaka T, Fukamizu A, Murakami K, Ishikawa K, Katori R. Significant role of the increase in reninangiotensin system in cardiac hypertrophy and renal glomerular sclerosis in double transgenic tsukuba hypertensive mice carrying both human renin and angiotensinogen genes. Clin Exp Hypertens 1998; 20: 439-449.

32 Sugiyama F, Haraoka S, Watanabe T, Shiota N, Taniguchi K, Ueno Y, Tanimoto K, Murakami K, Fukamizu A, Yagami K. Acceleration of atherosclerotic lesions in transgenic mice with hypertension by the activated renin-angiotensin system. Lab Invest 1997; 76: 835-842.

33 Grobe JL, Grobe CL, Beltz TG, Westphal SG, Morgan DA, Xu D, de Lange WJ, Li H, Sakai K, Thedens DR, Cassis LA, Rahmouni K, Mark AL, Johnson AK, Sigmund CD. The brain renin-angiotensin system controls divergent efferent mechanisms to regulate fluid and energy balance. Cell Metab 2010; 12: 431-442.

34 Daugherty A, Rateri DL, Lu H, Inagami T, Cassis LA. Hypercholesterolemia stimulates angiotensin peptide synthesis and contributes to atherosclerosis through the AT1A receptor. Circulation 2004; 110: 3849-3857. 
$35 \mathrm{Lu} \mathrm{H}$, Cassis LA, Daugherty A. Atherosclerosis and arterial blood pressure in mice. Curr Drug Targets 2007; 8: 1181-1189.

36 Lu H, Rateri DL, Feldman DL, Charnigo RJ Jr, Fukamizu A, Ishida J, Oesterling EG, Cassis LA, Daugherty A. Renin inhibition reduces hypercholesterolemia-induced atherosclerosis in mice. J Clin Invest 2008; 118: 984-993.

37 Daugherty A, Lu H, Rateri DL, Cassis LA. Augmentation of the renin-angiotensin system by hypercholesterolemia promotes vascular diseases. Future Lipidol 2008; 3: 625-636.

38 Lu H, Balakrishnan A, Howatt DA, Wu C, Charnigo R, Liau G, Cassis LA, Daugherty A. Comparative effects of different modes of renin angiotensin system inhibition on hypercholesterolaemia-induced atherosclerosis. $\mathrm{Br} J$ Pharmacol 2012; 165: 2000-2008.

39 Lu H, Wu C, Howatt DA, Balakrishnan A, Charnigo RJ Jr, Cassis LA, Daugherty A Differential effects of dietary sodium intake on blood pressure and atherosclerosis in hypercholesterolemic mice. J Nutr Biochem 2013; 24: 49-53.

40 Sinnayah P, Lazartigues E, Sakai K, Sharma RV, Sigmund CD, Davisson RL. Genetic ablation of angiotensinogen in the subfornical organ of the brain prevents the central angiotensinergic pressor response. Circ Res 2006; 99: 1125-1131.

41 Cassis LA, Saye J, Peach MJ. Location and regulation of rat angiotensinogen messenger RNA. Hypertension 1988; 11: 591-596.

42 Boustany CM, Bharadwaj K, Daugherty A, Brown DR, Randall DC, Cassis LA. Activation of the systemic and adipose renin-angiotensin system in rats with diet-induced obesity and hypertension. Am J Physiol Regul Integr Comp Physiol 2004; 287: R943-R949.

43 Cassis LA, Police SB, Yiannikouris F, Thatcher SE. Local adipose tissue reninangiotensin system. Curr Hypertens Rep 2008; 10: 93-98.

44 Postic C, Magnuson MA. DNA excision in liver by an albumin-Cre transgene occurs progressively with age. Genesis 2000; 26: 149-150.

45 Olearczyk J, Gao S, Eybye M, Yendluri S, Andrews L, Bartz S, Cully D, Tadin-Strapps M. Targeting of hepatic angiotensinogen using chemically modified siRNAs results in significant and sustained blood pressure lowering in a rat model of hypertension. Hypertens Res 2014; 37: 405-412.

46 Saigusa T, Dang Y, Mullick AE, Yeh ST, Zile MR, Baicu CF, Bell PD. Suppressing angiotensinogen synthesis attenuates kidney cyst formation in a Pkd1 mouse model. FASEB J 2016; 30: 370-379.

47 Ravichandran K, Ozkok A, Wang Q, Mullick AE, Edelstein CL. Antisense-mediated angiotensinogen inhibition slows polycystic kidney disease in mice with a targeted mutation in Pkd2. Am J Physiol Renal Physiol 2015; 308: F349-F357.

48 Yanai K, Saito T, Kakinuma Y, Kon Y, Hirota K, Taniguchi-Yanai K, Nishijo N Shigematsu Y, Horiguchi H, Kasuya Y, Sugiyama F, Yagami K, Murakami K, Fukamizu A. Renin-dependent cardiovascular functions and renin-independent blood- brain barrier functions revealed by renin-deficient mice. J Biol Chem 2000; 275: 5-8.

49 Krege JH, John SW, Langenbach LL, Hodgin JB, Hagaman JR, Bachman ES, Jennette JC, O'Brien DA, Smithies O. Male-female differences in fertility and blood pressure in ACE-deficient mice. Nature 1995; 375: 146-148.

50 Oliverio MI, Kim HS, Ito M, Le T, Audoly L, Best CF, Hiller S, Kluckman K, Maeda N, Smithies O, Coffman TM. Reduced growth, abnormal kidney structure, and type 2 (AT2) angiotensin receptor-mediated blood pressure regulation in mice lacking both AT1A and AT1B receptors for angiotensin II. Proc NatI Acad Sci USA 1998; 95 $15496-15151$

51 Takahashi N, Li F, Hua K, Deng J, Wang CH, Bowers RR, Bartness TJ, Kim HS, Harp JB. Increased energy expenditure, dietary fat wasting, and resistance to diet-induced obesity in mice lacking renin. Cell Metab 2007; 6: 506-512.

52 Jayasooriya AP, Mathai ML, Walker LL, Begg DP, Denton DA, Cameron-Smith D, Egan GF, McKinley MJ, Rodger PD, Sinclair AJ, Wark JD, Weisinger HS, Jois M, Weisinge RS. Mice lacking angiotensin-converting enzyme have increased energy expenditure, with reduced fat mass and improved glucose clearance. Proc Natl Acad Sci USA 2008; 105: 6531-6536.

53 Fukamizu A, Seo MS, Hatae T, Yokoyama M, Nomura T, Katsuki M, Murakami K. Tissue-specific expression of the human renin gene in transgenic mice. Biochem. Biophys. Res. Comm 1989; 165: 826-832.

54 Sigmund CD, Jones CA, Kane CM, Wu C, Lang JA, Gross KW. Regulated tissue- and cell-specific expression of the human renin gene in transgenic mice. Circ Res 1992; 70 1070-1079.

55 Uehara S, Tsuchida M, Kanno T, Sasaki M, Nishikibe M, Fukamizu A. Late-onset obesity in mice transgenic for the human renin gene. Int J Mol Med 2003; 11 723-727.

56 Chen XC, Lu H, Zhao M, Tashiro K, Cassis LA, Daugherty A. Angiotensin-converting enzyme promotes atherosclerosis through an angiotensin I to angiotensin II pathway involving leukocytes. Arterioscler Thromb Vasc Biol 2013; 33: 2075-2080.

57 Ito M, Oliverio MI, Mannon PJ, Best CF, Maeda N, Smithies O, Coffman TM. Regulation of blood pressure by the type $1 \mathrm{~A}$ angiotensin II receptor gene. Proc Natl Acad Sci USA 1995; 92: 3521-3525

58 Sugaya T, Nishimatsu S, Tanimoto K, Takimoto E, Yamagishi T, Imamura K, Goto S, Imaizumi K, Hisada Y, Otsuka A. Angiotensin II type 1a receptor-deficient mice with hypotension and hyperreninemia. J Biol Chem 1995; 270: 18719-18722.

59 Oliverio MI, Madsen K, Best CF, Ito M, Maeda N, Smithies O, Coffman TM. Renal growth and development in mice lacking AT1A receptors for angiotensin II. Am J Physiol 1998; 274: F43-F50.

60 Cassis LA, Rateri DL, Lu H, Daugherty A. Bone marrow transplantation reveals that recipient AT1a receptors are required to initiate angiotensin II-induced atherosclerosis and aneurysms. Arterioscler Thromb Vasc Biol 2007; 27: 380-386.

61 Nabeshima Y, Tazuma S, Kanno K, Hyogo H, Chayama K. Deletion of angiotensin I type I receptor reduces hepatic steatosis. J Hepatol 2009; 50: 1226-1235.
62 Gembardt F, Heringer-Walther S, van Esch JH, Sterner-Kock A, van Veghel R, Le TH, Garrelds IM, Coffman TM, Danser AH, Schultheiss HP, Walther T. Cardiovascular phenotype of mice lacking all three subtypes of angiotensin II receptors. FASEB $J$ 2008; 22: 3068-3077.

63 Poduri A, Owens AP 3rd, Howatt DA, Moorleghen JJ, Balakrishnan A, Cassis LA, Daugherty A. Regional variation in aortic AT1b receptor mRNA abundance is associated with contractility but unrelated to atherosclerosis and aortic aneurysms. PLOS ONE 2012; 7: e48462.

64 van Esch JH, Gembardt F, Sterner-Kock A, Heringer-Walther S, Le TH, Lassner D, Stijnen T, Coffman TM, Schultheiss HP, Danser AH, Walther T. Cardiac phenotype and angiotensin II levels in AT1a, AT1b, and AT2 receptor single, double, and triple knockouts. Cardiovasc Res 2010; 86: 401-409.

65 Ichiki T, Labosky PA, Shiota C, Okuyama S, Imagawa Y, Fogo A, Niimura F, Ichikawa I, Hogan BL, Inagami T. Effects on blood pressure and exploratory behaviour of mice lacking angiotensin II type-2 receptor. Nature 1995; 377: 748-750.

66 Daugherty A, Rateri DL, Howatt DA, Charnigo R, Cassis LA. PD123319 augments angiotensin II-induced abdominal aortic aneurysms through an AT2 receptorindependent mechanism. PLOS ONE 2013; 8: e61849.

67 Stucchi P, Cano V, Ruiz-Gayo M, Fernandez-Alfonso MS. Aliskiren reduces body-weight gain, adiposity and plasma leptin during diet-induced obesity. Br J Pharmacol 2009, 158: 771-778.

68 Iwai M, Kanno H, Tomono Y, Inaba S, Senba I, Furuno M, Mogi M, Horiuchi M. Direct renin inhibition improved insulin resistance and adipose tissue dysfunction in type 2 diabetic KK-A(y) mice. J Hypertens 2010; 28: 1471-1481.

69 Ino J, Kojima C, Osaka M, Nitta K, Yoshida M. Dynamic observation of mechanicallyinjured mouse femoral artery reveals an antiinflammatory effect of renin inhibitor. Arterioscler Thromb Vasc Biol 2009; 29: 1858-1863.

70 Frantz ED, Penna-de-Carvalho A, Batista Tde M, Aguila MB, Mandarim-de-Lacerda CA. Comparative effects of the renin-angiotensin system blockers on nonalcoholic fatty liver disease and insulin resistance in C57BL/6 mice. Metab Syndr Relat Disord 2014; 12 191-201.

71 Thomas CM, Yong QC, Seqqat R, Chandel N, Feldman DL, Baker KM, Kumar R. Direct renin inhibition prevents cardiac dysfunction in a diabetic mouse model: comparison with an angiotensin receptor antagonist and angiotensin-converting enzyme inhibitor. Clin Sci (Lond) 2013; 124: 529-541.

72 Dong YF, Liu L, Lai ZF, Yamamoto E, Kataoka K, Nakamura T, Fukuda M, Tokutomi Y, Nako $H$, Ogawa $H$, Kim-Mitsuyama S. Aliskiren enhances protective effects of valsartan against type 2 diabetic nephropathy in mice. J Hypertens 2010; 28: 1554-1565.

73 Kang YS, Lee MH, Song HK, Hyun YY, Cha JJ, Ko GJ, Kim SH, Lee JE, Han JY, Cha DR Aliskiren improves insulin resistance and ameliorates diabetic vascular complications in db/db mice. Nephrol Dial Transplant 2011; 26: 1194-1204.

74 Ye Y, Qian J, Castillo AC, Perez-Polo JR, Birnbaum Y. Aliskiren and Valsartan reduce myocardial AT1 receptor expression and limit myocardial infarct size in diabetic mice. Cardiovasc Drugs Ther 2011; 25: 505-515.

75 Jain S, Vinukonda G, Fiering SN, Kumar A. A haplotype of human angiotensinogen gene containing -217A increases blood pressure in transgenic mice compared with -217G. Am J Physiol Regul Integr Comp Physiol 2008; 295: R1849-R1857.

76 Jeunemaitre X, Soubrier F, Kotelevtsev YV, Lifton RP, Williams CS, Charru A, Hunt SC, Hopkins PN, Williams RR, Lalouel JM, Corvol P. Molecular basis of human hypertension: role of angiotensinogen. Cell 1992; 71: 169-180.

77 Jeunemaitre X, Ledru F, Battaglia S, Guillanneuf MT, Courbon D, Dumont C, Darmon O Guize L, Guermonprez JL, Diebold B, Ducimetiere P. Genetic polymorphisms of the renin-angiotensin system and angiographic extent and severity of coronary artery disease: the CORGENE study. Hum Genet 1997; 99: 66-73.

78 Iso H, Harada S, Shimamoto T, Sato S, Kitamura A, Sankai T, Tanigawa T, lida M, Komachi Y. Angiotensinogen T174M and M235T variants, sodium intake and hypertension among non-drinking, lean Japanese men and women. J Hypertens 2000; 18: 1197-1206.

79 Pan WH, Chen JW, Fann C, Jou YS, Wu SY. Linkage analysis with candidate genes: the Taiwan young-onset hypertension genetic study. Hum Genet 2000; 107 210-215.

80 Rankinen T, Gagnon J, Perusse L, Chagnon YC, Rice T, Leon AS, Skinner JS, Wilmore JH, Rao DC, Bouchard C. AGT M235T and ACE ID polymorphisms and exercise blood pressure in the HERITAGE Family Study. Am J Physiol Heart Circ Physiol 2000; 279: H368-H374.

81 Brand E, Chatelain N, Keavney B, Caulfield M, Citterio L, Connell J, Grobbee D, Schmidt S, Schunkert H, Schuster H, Sharma AM, Soubrier F. Evaluation of the angiotensinogen locus in human essential hypertension: a European study. Hypertension 1998; 31: 725-729.

82 Bengtsson K, Orho-Melander M, Lindblad U, Melander O, Bog-Hansen E, Ranstam J, Rastam L, Groop L. Polymorphism in the angiotensin converting enzyme but not in the angiotensinogen gene is associated with hypertension and type 2 diabetes: the Skaraborg Hypertension and diabetes project. J Hypertens 1999; 17 1569-1575.

83 Taittonen L, Uhari M, Kontula K, Kainulainen K, Miettinen H, Turtinen J, Nuutinen M. Angiotensin converting enzyme gene insertion/deletion polymorphism, angiotensinogen gene polymorphisms, family history of hypertension, and childhood blood pressure. Am J Hypertens 1999; 12: 858-866.

84 Kato N, Sugiyama T, Morita H, Kurihara H, Furukawa T, Isshiki T, Sato T, Yamori Y, Yazaki Y. Comprehensive analysis of the renin-angiotensin gene polymorphisms with relation to hypertension in the Japanese. J Hypertens 2000; 18 $1025-1032$. 
85 Larson N, Hutchinson R, Boerwinkle E. Lack of association of 3 functional gene variants with hypertension in African Americans. Hypertension 2000; 35: 1297-1300.

86 Province MA, Boerwinkle E, Chakravarti A, Cooper R, Fornage M, Leppert M, Risch N, Ranade K. Lack of association of the angiotensinogen-6 polymorphism with blood pressure levels in the comprehensive NHLBI Family Blood Pressure Program. National Heart, Lung and Blood Institute. J Hypertens 2000; 18: 867-876.

87 Wang L, Zhang B, Li M, Li C, Liu J, Liu Y, Wang Z, Zhou J, Wen S. Association between single-nucleotide polymorphisms in six hypertensive candidate genes and hypertension among northern Han Chinese individuals. Hypertens Res 2014; 37: 1068-1074.

88 Yasue S, Masuzaki H, Okada S, Ishii T, Kozuka C, Tanaka T, Fujikura J, Ebihara K, Hosoda K, Katsurada A, Ohashi N, Urushihara M, Kobori H, Morimoto N, Kawazoe T, Naitoh M, Okada M, Sakaue H, Suzuki S, Nakao K. Adipose tissue-specific regulation of angiotensinogen in obese humans and mice: impact of nutritional status and adipocyte hypertrophy. Am J Hypertens 2010; 23: 425-431.

89 Engeli S, Bohnke J, Gorzelniak K, Janke J, Schling P, Bader M, Luft FC, Sharma AM. Weight loss and the renin-angiotensin-aldosterone system. Hypertension 2005; 45: 356-362.

90 Oberbach A, Schlichting N, Neuhaus J, Kullnick Y, Lehmann S, Heinrich M, Dietrich A, Mohr FW, von Bergen M, Baumann S. Establishing a reliable multiple reaction monitoring-based method for the quantification of obesity-associated comorbidities in serum and adipose tissue requires intensive clinical validation. J Proteome Res 2014; 13: $5784-5800$.

91 van Harmelen V, Elizalde M, Ariapart P, Bergstedt-Lindqvist S, Reynisdottir S, Hoffstedt J, Lundkvist I, Bringman S, Arner P. The association of human adipose angiotensinogen gene expression with abdominal fat distribution in obesity. Int J Obes Relat Metab Disord 2000; 24: 673-678.
92 Demura M, Demura Y, Takeda Y, Saijoh K. Dynamic regulation of the angiotensinogen gene by DNA methylation, which is influenced by various stimuli experienced in daily life. Hypertens Res 2015; 38: 519-527.

93 Van Harmelen V, Ariapart P, Hoffstedt J, Lundkvist I, Bringman S, Arner P. Increased adipose angiotensinogen gene expression in human obesity. Obes Res 2000; 8: 337-341.

94 Jones BH, Standridge MK, Taylor JW, Moustaid N. Angiotensinogen gene expression in adipose tissue: analysis of obese models and hormonal and nutritional control. Am J Physiol 1997; 273: 236-242.

95 Krskova K, Filipcik P, Zilka N, Olszanecki R, Korbut R, Gajdosechova L, Zorad S. Angiotensinogen and angiotensin-converting enzyme mRNA decrease and AT1 receptor mRNA and protein increase in epididymal fat tissue accompany age-induced elevation of adiposity and reductions in expression of GLUT4 and peroxisome proliferatoractivated receptor (PPARgamma). J Physiol Pharmacol 2011; 62: 403-410.

(c) (i) (2) (2) This work is licensed under a Creative Commons Attribution-NonCommercial-ShareAlike 4.0 International License. The images or other third party material in this article are included in the article's Creative Commons license, unless indicated otherwise in the credit line; if the material is not included under the Creative Commons license, users will need to obtain permission from the license holder to reproduce the material. To view a copy of this license, visit http://creativecommons.org/licenses/bync-sa/4.0/ 